\title{
Pullout of Geosynthetic Reinforcement with In-plane Drainage Capability
}

\author{
J.G. Zornberg ${ }^{1}$ and Y. Kang ${ }^{2}$ \\ ${ }^{1}$ Civil Engineering Department, University of Texas at Austin, Austin, TX 78712; \\ PH (512) 232-3595; FAX (512) 471-6548; email: zornberg@mail.utexas.edu \\ ${ }^{2}$ Civil Engineering Department, University of Texas at Austin, Austin, TX 78712; \\ email: happy072@mail.utexas.edu
}

\section{Abstract}

While there are significant economic reasons for relaxing the currently stringent specifications for backfill material in reinforced soil structures, it is also true that failure of these structures have often involved inadequate drainage and use of low quality, fine-grained soils. However, geosynthetic inclusions can be used within finegrained soils if they can provide not only reinforcement, but also lateral drainage. While using reinforcement with in-plane drainage capability is conceptually enticing, transmissivity requirements for such application have not been properly quantified. This study presents preliminary results of an ongoing experimental testing program involving geogrid pullout tests conducted in wet, fine-grained soils. Pairs of tests were conducted using geogrids with the same tensile strength but with and without in-plane drainage channels. The beneficial effect of lateral drainage is being quantified.

\section{Introduction}

The gradation requirements of the backfill used in reinforced soil structures are often very restrictive, as most agencies in the U.S. preclude the use of fine-grained backfill soils. While such stringent requirements have significant economic implications, there are concerns in relaxing these requirements since most failures in reinforced soil structures have involved the use of poorly draining backfills (Zornberg and Mitchell, 1994; Mitchell and Zornberg, 1995; Helwany, 1999). The Federal Highway Administration (FHWA) requires a maximum percent fines of $15 \%$ for mechanically stabilized earth (MSE) walls. The use of granular fill has been reported to be the most expensive component of a reinforced soil retaining system, typically corresponding to $40 \%$ of the total construction costs (Zeynep, 1992).

Concerns regarding the use of poorly draining soils as backfill materials include: (1) the lower shear strength that poorly draining soils (e.g. clays) have when compared 
with free draining soils (e.g. gravels), (2) the comparatively lower hydraulic conductivity of poorly draining soils, which may lead to infiltration and subsequent generation of pore water pressures, (3) soil freezing problems associated with poorly draining soils in cold regions, (4) corrosion of reinforcements when using metallic inclusions with poorly draining backfill materials, and (5) the comparatively high creep potential of poorly draining backfill materials. However, most of these concerns can be addressed if good internal drainage is provided by using geosynthetic reinforcements with in-plane drainage capabilities. Accordingly, the selected geosynthetic should have not only adequate tensile strength to satisfy external and internal stability requirements, but also adequate transmissivity to dissipate possible positive pore water pressure. The objective of this project is to generate experimental data suitable for quantifying the in-plane drainage requirements.

\section{Materials and Methods}

Geosynthetics with in-plane drainage capabilities considered to reinforce poorly draining soils specifically include reinforced nonwoven geotextiles [Figure 1(a)] and geogrids with in-plane drainage channels [Figure 1(b)]. The first product is a continuous polypropylene filament nonwoven geotextile reinforced by a biaxial grid network of polyester yarns, while the second is a geogrid with polyester filament core with polyethylene sheath and drainage channels involving a polypropylene and polyethylene nonwoven geotextile. It should be noted that there are other available products that serve both reinforcement and drainage functions simultaneously.

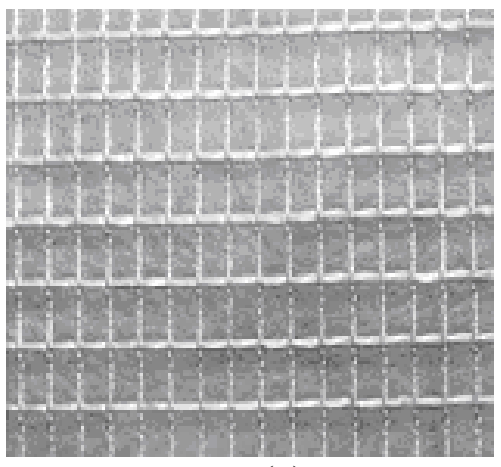

(a)

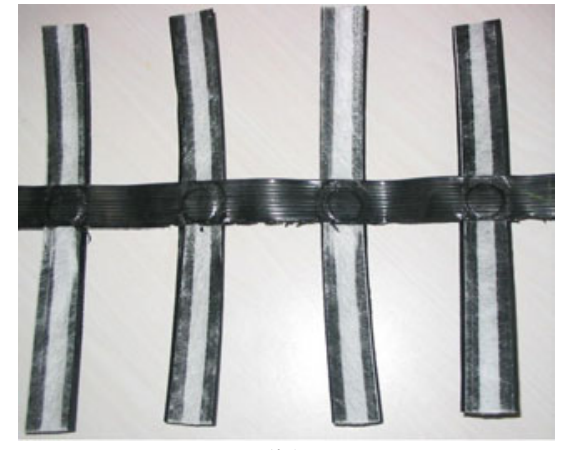

(b)

Figure 1. Geosynthetic reinforcements with in-plane drainage capabilities : (a) high strength nonwoven geotextile, (b) geogrid with in-plane drainage channel.

Pullout tests are being conducted at the University of Texas at Austin to compare the behavior of geosynthetic reinforcement embedded in wet, poorly draining soils. Two types of geosynthetics are being used in the testing program. Specifically, geogrids manufactured using materials of similar tensile strength, but with and without inplane drainage channels, are being used in a pullout testing program. The geogrids are manufactured by Terram and commercialized as Paragrid 100/15 and Paradrain 100/15. Table 1 summarizes the properties of these geosynthetic materials. 
A silty soil is used as backfill material in the pullout testing program. The soil has a comparatively low hydraulic conductivity of $2.7 \times 10^{-5} \mathrm{~cm} / \mathrm{sec}$ and classifies as CL according to the Unified Soil Classification System (USCS). Table 2 summarizes the properties of the silty soil and Figure 2 shows the gradation curve for the soil.

Table 1. Properties of the Geosynthetic Materials

\begin{tabular}{llll}
\hline Property & & $\begin{array}{l}\text { Geogrid by } \\
\text { itself }\end{array}$ & $\begin{array}{l}\text { Geogrid with } \\
\text { in-plane } \\
\text { drainage } \\
\text { layer }\end{array}$ \\
\hline $\begin{array}{l}\text { Ultimate } \\
\begin{array}{l}\text { Tensile strength } \\
(\mathrm{kN} / \mathrm{m})\end{array}\end{array}$ & $\begin{array}{l}\text { Machine direction } \\
\text { Cross-machine direction }\end{array}$ & 100 & 100 \\
$\begin{array}{l}\text { Strain at rupture (Machine direction) } \\
\text { Transmissivity under 100 } \mathrm{kPa}\end{array}$ & $(\%)$ & 12 & 15 \\
$\begin{array}{l}\text { (Hydraulic Gradient }=1.0) \\
\text { Unit mass }\end{array}$ & $\left(\mathrm{m}^{2} / \mathrm{s}\right)$ & - & 12 \\
Thickness & $\left(\mathrm{g} / \mathrm{m}^{2}\right)$ & 490 & $1.06 \times 10^{-6}$ \\
\hline
\end{tabular}

Table 2. Soil Oroperties

\begin{tabular}{cc}
\hline Specific gravity & 2.71 \\
Liquid limit (\%) & 29 \\
Plastic limit (\%) & 12 \\
Plasticity index $(\%)$ & 17 \\
Optimum moisture content $(\%)^{*}$ & 12.9 \\
Maximum dry unit weight $\left(\mathrm{kN} / \mathrm{m}^{3}\right)^{*}$ & 18.67 \\
\hline
\end{tabular}

* According to Standard proctor test

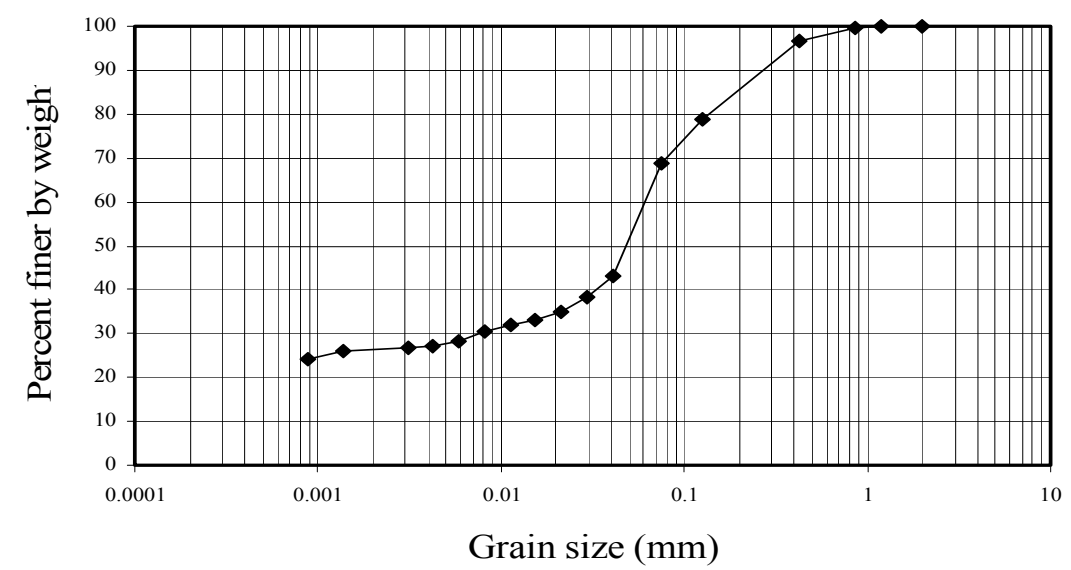

Figure 2. Granulometric Curve of silty soil used in the testing program. 
The pullout tests are performed using a large-scale pullout box (Figure 3) with dimensions of $1520 \mathrm{~mm}$ (length) $\times 610 \mathrm{~mm}$ (width) $\times 280 \mathrm{~mm}$ (height). The box is equipped with hydraulic jacks for application of the pullout force. The normal pressure is applied using an inflatable air bag placed between the soil surface and a heavy steel box cover. A slit on the front side of the box is used to grip the geosynthetic, while a slit on the back side is used for displacement measurement using tell-tales attached to linear variable displacement transformers (LVDTs). Four LVDTs and a load cell are used to monitor the displacements along the geosynthetic and the pullout force, respectively. In addition, pore water pressure transducers are being used to measure pore pressures generated within the soil mass, in the vicinity of the geosynthetic. Figure 4 shows a plan view and a schematic diagram of the pullout test.

Soil placement procedures involve conditioning to a water content of $20 \%$, which is well above the optimum water content of the soil (12.9\%), and compacting the soil to a dry unit weight of $17.92 \mathrm{kN} / \mathrm{m}^{3}$, which corresponds to a relative compaction of $80 \%$. After placing the soil in the lower half the box, the geosynthetic, tell-tales, LVDTs, and pore water pressure transducers are installed. The soil above the geosynthetic is subsequently placed in the upper box. Finally, the rubber air bag, placed between soil surface and a heavy steel plate is pressurized to the target normal pressure. Pore water pressures are allowed to dissipate during twenty minutes before the pullout load is applied using a standard displacement rate of $2 \mathrm{~mm} / \mathrm{min}$. An automated data acquisition system is used to measure displacements, pore water pressures and the pullout load.

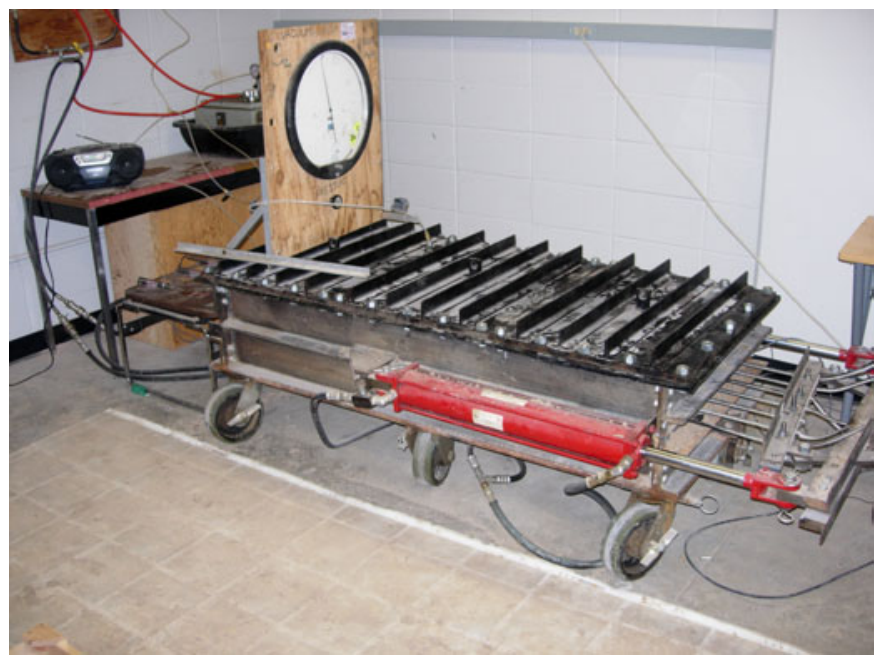

Figure 3. Large scale pullout box.

\section{Preliminary Results}

Preliminary pullout test results obtained using geogrids with and without in-plane drainage layers are presented in this paper. The data collected in these tests include pore water pressures, displacements along the geosynthetic reinforcement and pullout force. Backfill soil prepared using the same compaction procedures $\left(\mathrm{w}=20 \% ; \gamma_{\mathrm{d}}=\right.$ 
$\left.17.92 \mathrm{kN} / \mathrm{m}^{3}\right)$ and a normal pressure of $41 \mathrm{kPa}(6 \mathrm{psi})$ was used in both tests. Figure 5 shows the displacements measured using LVDT 1 (frontal displacement) as a function of pullout force.
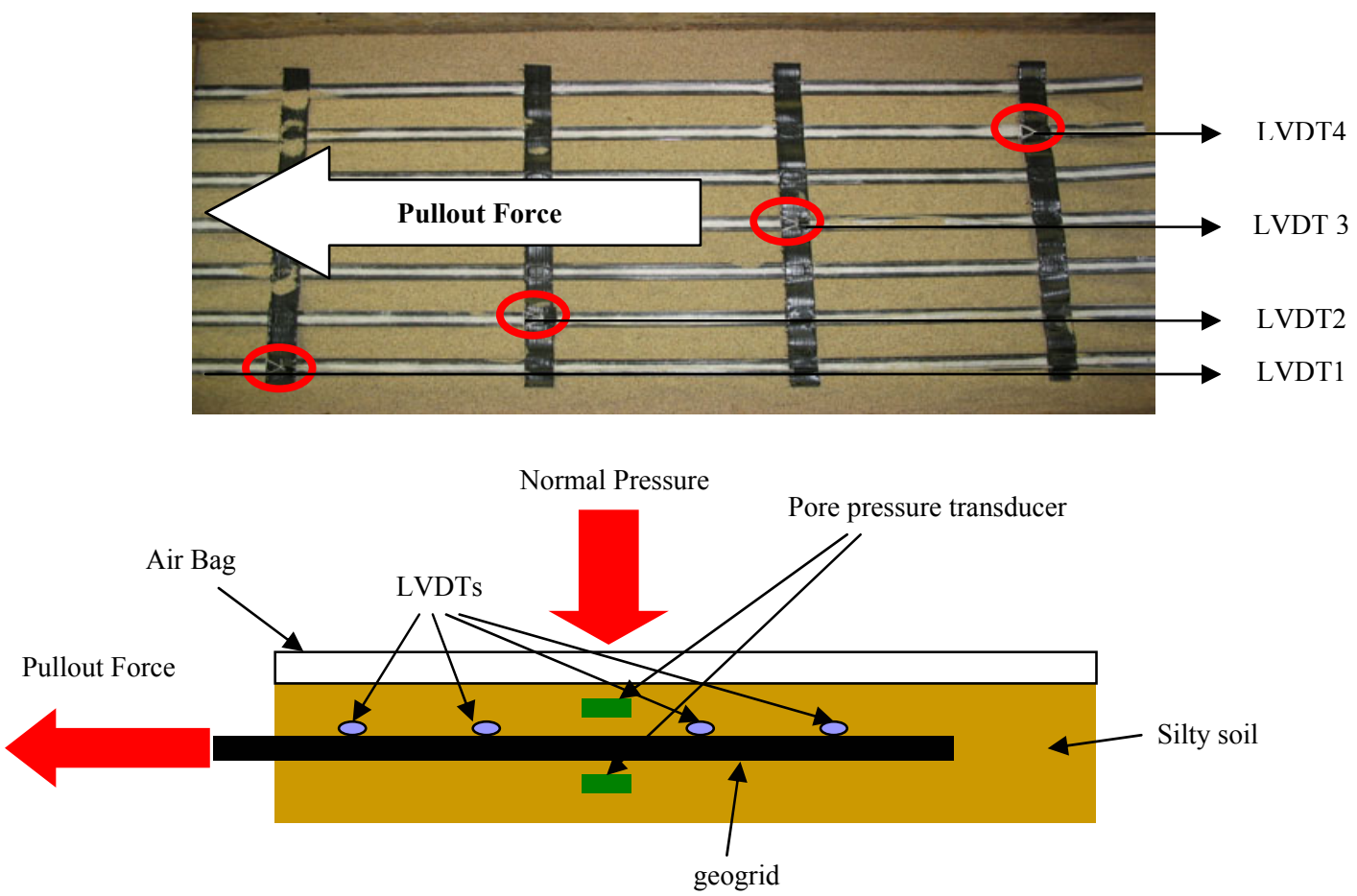

Figure 4. Pullout test: a) plan view; b) schematic cross-section.

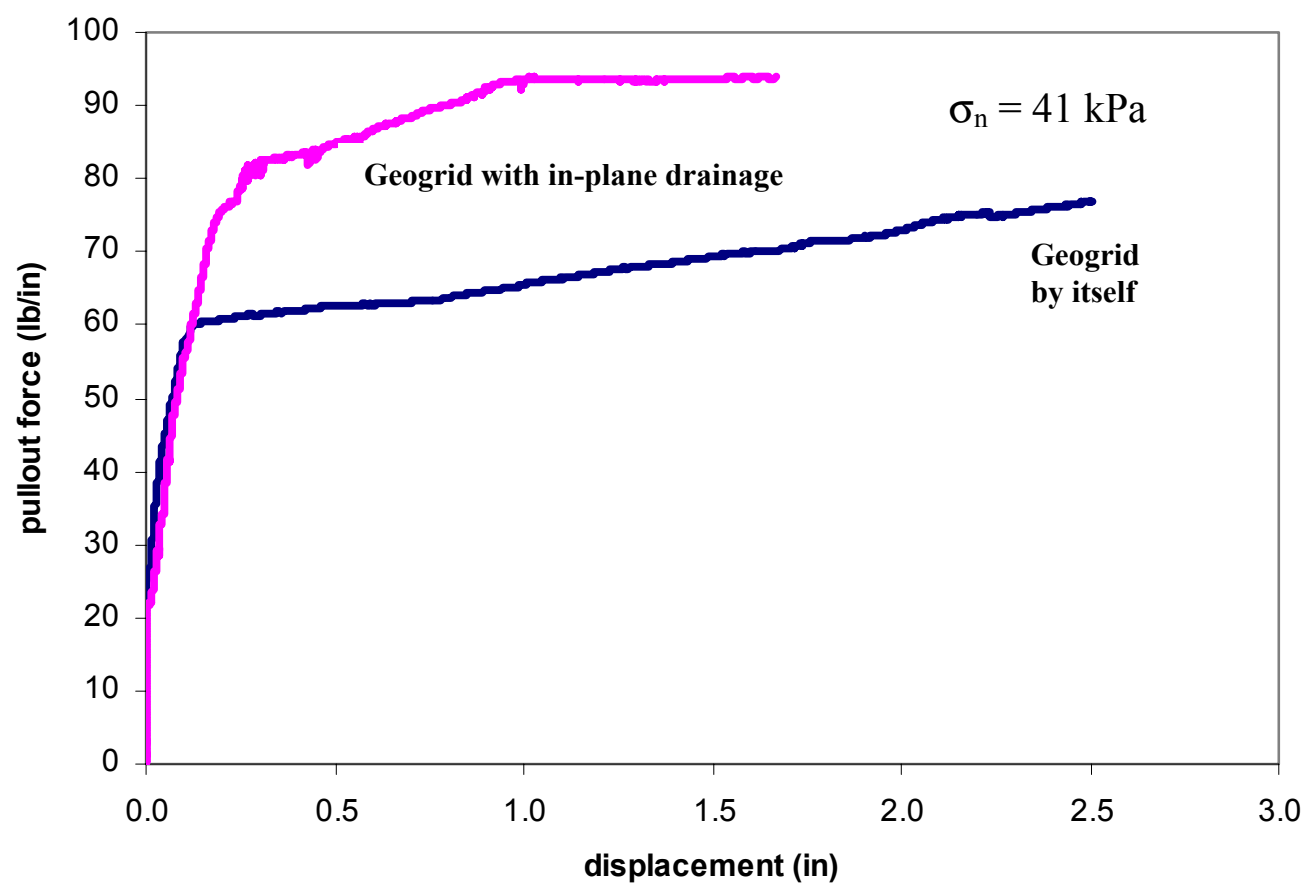

Figure 5. Pullout test results obtained using geogrids with and without drainage layers. 
As shown in the figure, the geogrid with in-plane drainage layers provides a higher resistance than the geogrid without drainage. Specifically, most of the pullout resistance (measured at break in the pullout force - displacement curve) is mobilized at approximately 0.2 in of displacement. This corresponds to a pullout resistance of approximately $10.5 \mathrm{kN} / \mathrm{m}$ for the geogrid and to a resistance of approximately 14.2 $\mathrm{lb} /$ in for the geogrid with in-plane drainage. Consequently, the use of in-plane drainage leads to an increase of approximately $30 \%$ in the pullout resistance for the soil placement and loading conditions used in this test. The results show a continued increase in pullout resistance for longer displacements, which may be attributed to time-dependent increase in resistance due to continued dissipation of pore water pressure through the soil mass.

\section{Expected Findings}

The preliminary results obtained in this study confirm that geosynthetic products with in-plane drainage capacity provide an increased pullout resistance as they can dissipate shear-induced pore water pressures. Research is in progress to quantify the transmissivity requirements as a function of the soil properties and initial moisture conditions. To this effect, additional pullout tests are planned using a wide range of normal pressures, initial soil placement conditions and loading sequences.

\section{References}

Helwany, S.M.B., Reardon, G. and Wu, J.T.H. (1999) "Effects of backfill on the performance of GRS Retaining walls." Geotextiles and Geomembranes, Vol.17, pp. 1-16.

Mitchell, J.K. and Zornberg, J.G. (1995) "Reinforced soil structures with poorly draining backfills. Part II: Case histories and applications". Geosynthetics International, Vol.2, No. 1, pp. 265-307.

Zeynep, D. and Tezcan, S. (1992). "Cost Analysis of Reinforced Soil Walls." Geotextiles and Geomembranes, Vol. 11, No. 1, pp. 29-43.

Zornberg, J.G. and Mitchell, J.K. (1994) "Reinforced soil structures with poorly draining backfills. Part I: Reinforcement interactions and functions." Geosynthetics International, Vol.1, No. 2, pp. 103-148. 